\title{
Disruption and Strategic Outsourcing to the Competitor in the Common Market
}

Zhaoqiong Qin, University of Central Oklahoma, Edmond, USA

\begin{abstract}
There are circumstances that one firm will outsource (purchase) products to its competitor in the common market when experiencing an unexpected supply disruption. Such strategies to hedge against the unexpected supply disruption commonly suffers from the higher wholesale price charged by its competitor although it helps maintain its presence on the market. Its competitor also is concerned about encroachment to sell the products to the firm as a rival in the common market. Mathematical models are formulated to maximize each party's profit in both cases of outsourcing and not outsourcing under decentralization and centralization. The results show that both parties benefit from the strategy of outsourcing at the time of disruption. More interestingly, the results also show that the competitor's centralized decision-making is preferred.
\end{abstract}

\section{KEYWORDS}

Central Decision Making, Outsourcing, Supply Chain, Supply Disruption

\section{INTRODUCTION}

With the increase of offshoring, globalization and demand uncertainty, supply shortage and disruption risk have become the pressing issues in supply chains. These kinds of issues have become more severe following external factors (for instance, natural disasters), or internal factors (e.g., machine breakdowns). The typical examples are automotive manufacturers after March 11, 2011 Tohoku earthquake off the eastern coast of Japan - Over 400 parts in Toyota were in immediate shortage and production capacity was reduced for 6 months following the disaster (Tabuchi, 2011). Moreover, a recent explosion at the production plant of Evonik, a big supplier of a specialty resin for auto parts in Germany, led to significant inventory shortfalls (Bennett and Hromadko, 2012). Similarly, the flooding in Thailand hurt the supply of disk drives and related components from Intel (Clark, 2012b). Samsung mitigated the supply shortage through outsourcing the Galaxy S4's processor to its rival chipmaker Qualcomm in several countries when it couldn't produce enough of its own Exynos 5 Octa processor (Nguyen, 2013). Clearly, outsourcing products to competitors can mitigate the supply shortage and disruption risk.

Outsourcing products to competitors is in fashion in many industries. For example, Ford Probe is produced by Mazda Motor Co. and then competes against MX-6 in the sports car market; Zenith Electronics builds laptop PCs for Hewlett-Packard; and Lockheed produces parts for Boeing's 
commercial aircraft (Spiegel, 1993). Apparently, these outsourcing strategies directly affect the profits of the sourcing companies and their competitors. When companies face the supply shortage and disruption risk, whether they would outsource products to their competitors and competitors would provide products to help hedge against the disruption or shortage should be evaluated. So far previous research has shed little light on the strategies of outsourcing to competitors in the common market to hedge against the supply shortage or disruption risk. We aim to fill this gap in the literature.

In this study, there are two firms Firm 1 and Firm 2 to deliver the perfect substitutable products to the common market. Firm 1 is steady with enough capacity while Firm 2 may experience unexpected supply disruption. When the potential disruptive firm experiences the unexpected supply disruption, it can choose either to purchase the products from Firm 1 to still maintain its presence on the market or not to purchase and just to be absent from the market. We build mathematical models to study the steady firm's incentives to choose its supply chain structure (centralized or decentralized) and the potential disruptive firm's strategic outsourcing decisions (outsourcing or not) at the time of disruption. We examine how the steady firm's supply chain structure and the potential disruptive firm's outsourcing strategies affect both firms' performance in the presence of the disruption risk $\lambda$. Based on the firms' performance, how should the steady firm make the decision in its supply chain structure and the potential disruptive firm make the decision in outsourcing? Specifically, we consider two competitors in the common market. They involve in the Cournot competition with perfect substitutability. Firm 2 faces the unexpected supply disruption risk while Firm 1 has ample steady supply. When supply disruption occurs, Firm 1 can choose whether to outsource products from its competitor to beat the supply shortage based on the sourcing agreement between them or not to outsource and be absent from the market. The objective of these two competitors is to maximize their own profits. We try to answer the following research questions: 1) Will it purchase the products from Firm 1 when Firm 2 experiences the disruption? 2) How will Firm 1 make the decision in its supply chain structure, centralized decision making by selling its products to the market directly on its own or decentralized decision making by selling through an independent retailer?

Our results deliver several insights. First, we demonstrate that both competitors have incentives to create outsourcing agreements for the potential disruptive firm (Firm 2) to purchase the products from the steady firm (Firm 1) in the event of supply disruption. That is to say, outsourcing benefits not only the disruptive party but also its competitor whom it will purchase products from at the time of disruption. From the disruptive party's standpoint, the strategic outsourcing not only maintains its presence on the market in the event of disruption but also achieves a higher profit compared to not outsourcing from its competitor. From its competitor Firm 1's standpoint, the strategic outsourcing of Firm 2 in the event of disruption offers an opportunity for Firm 1 to achieve a higher profit. Therefore, the strategic outsourcing to hedge against the disruption risk can create a win-win situation. Secondly, we find that Firm 1 will earn a higher profit in the centralized decision making. In other words, it is preferred for the steady firm to deliver its products to the market through a centralized supply chain.

\section{Related Literature}

The strategies to manage the risk of uncertain supply have been extensively explored in the existing disruption management literature. Among the typical examples are Hu and Kostamis (2014), Tomlin and Wang (2011), Tomlin (2009), Federgruen and Yang (2008), Yang et al. (2009), Wadecki et al. (2012), Yang and Volodymyr (2015), Ang, Iancu, and Swinney (2017) and Demirel, Kapuscinski and $\mathrm{Yu}$ (2018). When we consider the issue of risks in the supply uncertainty, our work is particularly related to the models with outsourcing to the competitors with certain supply in the common market to hedge against the risk of uncertain supply.

Traditionally there are two general approaches to build the model of uncertain supply: the random yield model, assuming that the output level is a random function of the input variables (Henig and Gerchak, 1990; Kouvelis and Li, 2013; Yang and Volodymyr, 2015; Ang, Iancu, and Swinney, 2017), and the total supply disruption model, assuming that it is the "all-or-nothing" 
form (Hu et al. 2013; Tomlin 2006). We adopt the total disruption model in which the supply is fully fulfilled, or nothing is fulfilled.

From the category of outsourcing, Arya, Mittendorf and Sappington (2008) considered that the monopolistic supplier served the retailer's rival in the common market while the retailer can either make the products in house or outsource the products from the monopolistic supplier. Their results showed that the retailer may pay a premium to outsource production from a common supplier in order to raise its rivals' costs only when the supplier is the least-cost producer of the products. In contrast to their models, we consider both firms have the same marginal costs through their own channels, among which one firm is steady with enough capacity while the other one may experience unexpected supply disruption. Our results show that in the event of supply disruption, the disruptive firm would always pay a premium to outsource the products from her competitor even if her competitor is not the least-cost producer of the products.

From the category of decentralization, Arya, Mittendorf and Yoon (2008) demonstrated that the manufacturer can benefit from his decentralized control of his retail supply chain when he provides the products to his rival in the common market. Our model differs from their model in that the steady firm provides the product to his rival with potential supply disruption in the common market only when his rival experiences unexpected disruption. Our results show that the steady firm actually benefits from his centralized control of his retail supply chain. That is, the centralized control of his retail supply chain is preferred.

From the category of strategies to mitigate the risk of uncertain supply, Chen and Guo (2014) investigated the incentives for the focal firm of two competitors to adopt the dual -sourcing strategy in the case of supply uncertainty: common supplier and alternative supplier. They found that the focal firm's dual-sourcing strategy to hedge against supply disruption risk can create a win-win situation that leads to increase retail prices and expected profits for both firms. Our model differs from theirs: on one hand, we assume that we adopt the total disruption model to describe the supply uncertainty while they adopted the simple random yield model; on the other hand, in their model, one of the two suppliers is common for the two competitors and the other one is alternative only for the focal firm. Compared to their model, our model assumes that one of two competitors have a steady supply while the other one may experience an unexpected disruption with rate $\lambda$. The steady competitor can provide the products to its rival when its rival experiences the disruption. We find that this kind of outsourcing strategy to hedge against the supply disruption risk can also create a win-win situation that leads to increase expected profits for both competitors.

To mitigate the risk of supply disruption, Yang and Volodymyr (2015) incorporate the service of a better-informed procurement service provider (PSP) into the study. They conclude that hiring a PSP cannot solve the problem of an unreliable supply base. Our study proposes a different strategysourcing from the reliable competitor to mitigate the risk of supply disruption.

To summarize, our model is, to the best of our knowledge, among the first to explore the strategy of outsourcing to competitors at the same production costs to hedge against disruptive supply, centralized control to benefit the firm and the first to consider how outsourcing to competitors to hedge against supply disruption creates a win-win situation by appropriately wholesale price contracts.

\section{Model}

In our study, we consider supply chain models consisting of two firms selling their products in the end consumer market. These two firms, labeled as Firm 1 and Firm 2, involve in the Cournot competition. They differ in their supply reliability. While Firm 1 has reliable supply and enough manufacturing capacity, Firm 2 has the probability $1-\lambda$ to supply the expected quantity and probability $\lambda$ to supply zero due to the unexpected disruption. We assume $\lambda \leq \frac{1}{2}$ to indicate that Firm 2 will not involve in the competition if the supply disruption is significant. When supply disruption occurs, Firm 2 can either purchase the products from Firm 1 to continue to maintain its 
presence on the market or not purchase from Firm 1 and then Firm 1 will monopoly the market. In other words, Firm 2 can make a choice between adopting an outsourcing strategy to its rival Firm 1 to continue the business and not adopting the outsourcing strategy to be absent from the market when supply disruption occurs.

Throughout the study, we assume that 1) firms are risk neutral; 2) the marginal costs to produce the products in both firms are the same; and 3) both firms have the common knowledge about each other's supply rates. Each firm optimally chooses its quantity, anticipating its rival's action. In the following paragraphs, we describe these two firms' competition in detail.

To simplify our exposition, we also assume that the products from both firms are homogeneous. Consumer demand is represented by a linear, downward-sloping demand function $p=a-q_{1}-q_{2}$, where $p$ is the retail price of the products on the market and $q_{i}$ is the quantity of the product delivered by Firm $i(i=1,2)$. Especially, if Firm 2 experiences supply disruption and does not outsource the products from Firm 1, then $q_{2}=0$.

Given this modeling framework, we first study the case that Firm 1 is a central decision maker and sells its products through its centralized supply chain in Section 3.1. Following this, we study the case that Firm 1 is a decentralized decision maker and sells ITs products through a retailer in its decentralized supply chain. Mathematical notations are summarized in Table 1.

\section{Outcomes in the Equilibrium When Firm 1 is a Central Decision Maker}

In this subsection, we consider the scenario that Firm 1 is a central decision maker and sells its products to the market through its centralized supply chain. Figure 1 shows the sequences of events in this scenario. As shown in the figure, Firm 1 announces the wholesale price per unit for Firm 2 to purchase products from him in the case of supply disruption. Following the announcement, Firm 2 decides to purchase to hedge against the supply uncertainty or not. Then both Firm 1 and Firm 2 decide the quantities of the product to deliver to the common market, respectively. In the context of Firm 2's decision of purchasing products from Firm 1 when disruption occurs, Firm 2 will deliver its own products to the market when its supply is smooth while it will purchase the product from Firm 1 when it experiences the supply disruption. Finally, both firms involve in the Cournot competition and the market clears based on the quantities of products from both firms. In the context of Firm 2's decision of not purchasing products from Firm 1, Firm 2 will not provide the product to the market when it experiences the supply disruption and then Firm 1 will monopoly the market. The market clears based on the quantities from Firm 1. However, both firms involve in the Cournot competition when Firm 2 does not experience the supply disruption and the market clears based on the quantities of products from both firms.

To analyze whether Firm 2 would purchase the products from its rival Firm 1 or not in the case of its supply disruption, we first obtain the outcomes that follow Firm 2's decision not to purchase when it experiences the supply disruption in Subsection 3.1.1. Then we derive the outcomes that follow Firm 2's decision to purchase when supply disruption occurs. We characterize the equilibrium outcomes when Firm 1 is a centralized decision maker in a centralized supply chain.

\section{The Regime in Firm 2's Decision of Not Purchasing From Firm 1 at the Time of its Supply Disruption}

In this subsection, we consider the regime that it does not purchase the products from the rival Firm 1 when Firm 2 experiences supply disruption.

Based on the sequences of the events in Figure 1, following Firm 1's announced wholesale price $w$ for Firm 2 to purchase, Firm 2 decides not to purchase products in the case of supply disruption. Following that, both firms will optimally decide the quantities of the product to deliver to the market, expecting the rival's rational action. In other words, Firm 1 chooses its output $q_{1}^{f}$ to maximize its 
Table 1. Modeling notation

\begin{tabular}{|c|}
\hline Variable/parameter Description \\
\hline$a$ : Market size \\
\hline$c:$ Marginal production cost \\
\hline$\lambda:$ Probability that Firm 2 is disrupted with supply "zero" \\
\hline $\begin{array}{l}q_{i}^{f}: \text { Quantity delivered by Firm } i(i=1,2) \text { when Firm } 1 \text { is a central decision maker and Firm } 2 \text { does not purchase } \\
\text { products from Firm } 1 \text { to hedge against disruption }\end{array}$ \\
\hline $\begin{array}{l}\pi_{i}^{f}: \text { Firm } i(i=1,2) \text { 's profit when Firm } 1 \text { is a central decision maker and Firm } 2 \text { does not purchase products from } \\
\text { Firm } 1 \text { to hedge against disruption }\end{array}$ \\
\hline $\begin{array}{l}q_{i}^{p} \text { : Quantity delivered by Firm } i(i=1,2) \text { when Firm } 1 \text { is a central decision maker and Firm } 2 \text { purchases products } \\
\text { from Firm } 1 \text { to hedge against disruption }\end{array}$ \\
\hline $\begin{array}{l}\pi_{i}^{p}: \text { Firm } i(i=1,2) \text { 's profit when Firm } 1 \text { is a central decision maker and Firm } 2 \text { purchases products from Firm } 1 \text { to } \\
\text { hedge against disruption }\end{array}$ \\
\hline $\begin{array}{l}w: \text { Wholesale price Firm 1charges Firm } 2 \text { when Firm } 1 \text { is a central decision maker and Firm } 2 \text { purchases products from } \\
\text { Firm } 1 \text { to hedge against disruption }\end{array}$ \\
\hline $\begin{array}{l}q_{j d}^{f} \text { : Quantity delivered by Firm } j(j=R, 2) \text { 's retailer when Firm } 1 \text { is a decentralized decision maker and Firm } 2 \\
\text { does not purchase products from Firm } 1 \text { to hedge against disruption }\end{array}$ \\
\hline $\begin{array}{l}\pi_{i d}^{f}: \text { Firm } i(i=1,2) \text { 's profit when Firm } 1 \text { is a decentralized decision maker and Firm } 2 \text { does not purchase products } \\
\text { from Firm } 1 \text { to hedge against disruption }\end{array}$ \\
\hline $\begin{array}{l}\pi_{R d}^{f}: \text { Profit of Firm 1's retailer when Firm } 1 \text { is a decentralized decision maker and Firm } 2 \text { does not purchase products } \\
\text { from Firm } 1 \text { to hedge against disruption }\end{array}$ \\
\hline $\begin{array}{l}w_{d}^{f}: \text { Wholesale price Firm } 1 \text { charges its retailer when Firm } 1 \text { is a decentralized decision maker and Firm } 2 \text { does not } \\
\text { purchase products from Firm } 1 \text { to hedge against disruption }\end{array}$ \\
\hline $\begin{array}{l}q_{j d}^{p} \text { : Quantity delivered by Firm } j(j=R, 2) \text { 's retailer when Firm } 1 \text { is a decentralized decision maker and Firm } 2 \\
\text { purchases products from Firm } 1 \text { to hedge against disruption }\end{array}$ \\
\hline $\begin{array}{l}\pi_{i d}^{p}: \text { Firm } i(i=1,2) \text { 's profit when Firm } 1 \text { is a decentralized decision maker and Firm } 2 \text { purchases products from } \\
\text { Firm } 1 \text { to hedge against disruption }\end{array}$ \\
\hline $\begin{array}{l}\pi_{R d}^{p}: \text { Profit of Firm 1's retailer when Firm } 1 \text { is a decentralized decision maker and Firm } 2 \text { purchases products from } \\
\text { Firm } 1 \text { to hedge against disruption }\end{array}$ \\
\hline $\begin{array}{l}w_{d}^{p}: \text { Wholesale price Firm } 1 \text { charges its retailer and Firm } 2 \text { when Firm } 1 \text { is a decentralized decision maker and Firm } 2 \\
\text { purchases products from Firm } 1 \text { to hedge against disruption }\end{array}$ \\
\hline
\end{tabular}




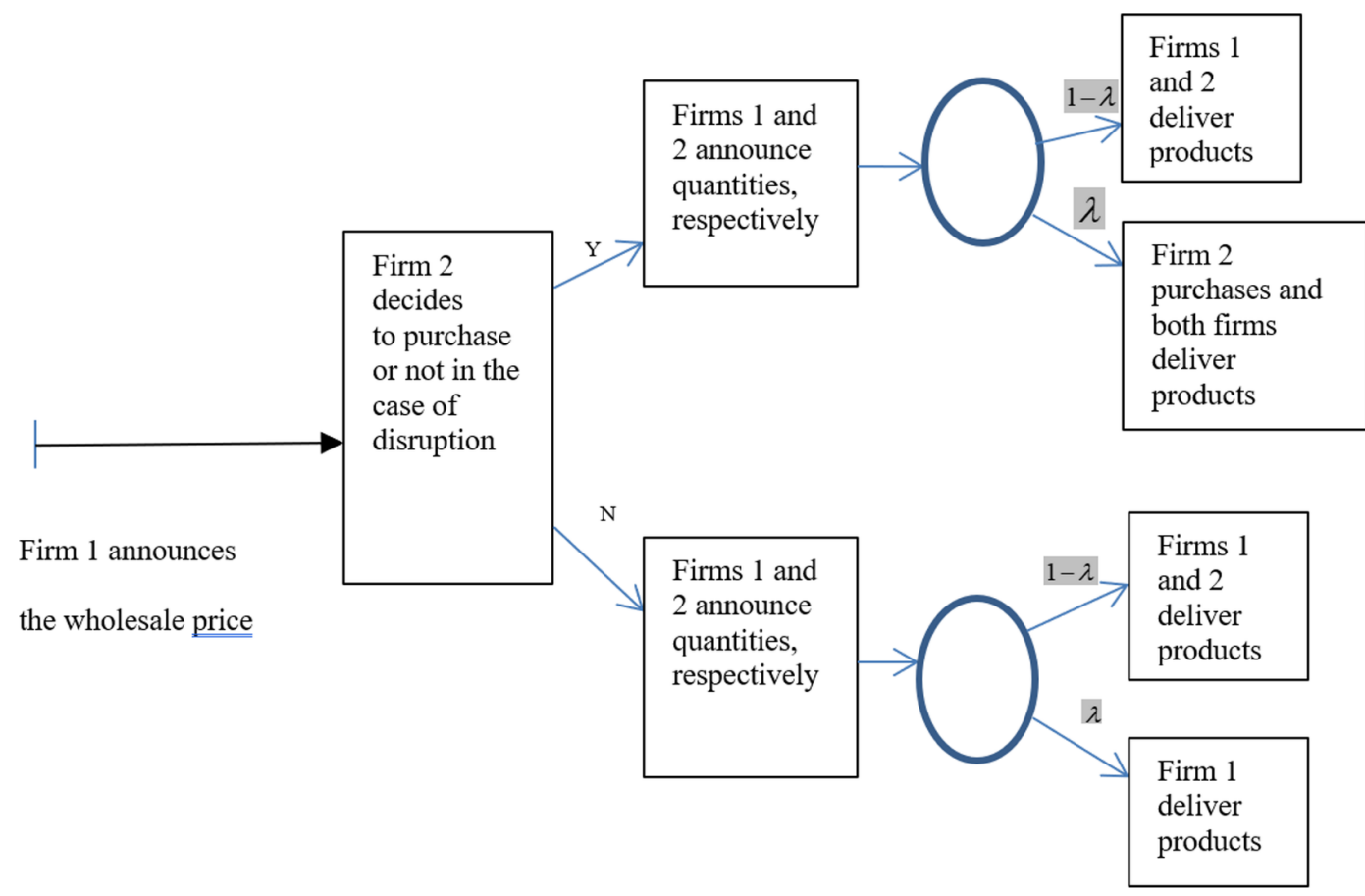

profit given both firms' unit production cost $c$ and Firm 2's output $q_{2}^{f}$. Mathematically, its profit $\pi_{1}^{f}$ can be formulated as follows in (1):

$\pi_{1}^{f}=(1-\lambda)\left(a-q_{1}^{f}-q_{2}^{f}-c\right) q_{1}^{f}+\lambda\left(a-q_{1}^{f}-c\right) q_{1}^{f}$

In Equation (1), $a-q_{1}^{f}-q_{2}^{f}$ represents the product's price to clear the quantity on the market based on the Cournot Model (Qin, 2013) when both firms deliver the products to the market as long as Firm 2 has no disruption. Therefore $a-q_{1}^{f}-q_{2}^{f}-c$ represents the net profit per unit of the product. $a-q_{1}^{f}-c$ represents the net profit per unit of the product when only Firm 1 delivers the products to the market under the case that Firm 2 disrupts and does not outsource to Firm 1. Therefore, the whole equation (1) represents the expected profit of Firm 1.

Similarly, Firm 2's profit $\pi_{2}^{f}$ as follows in (2):

$\pi_{2}^{f}=(1-\lambda)\left(a-q_{1}^{f}-q_{2}^{f}-c\right) q_{2}^{f}$

Equation (2) shows that Firm 2 obtain profits only when Firm 2 has no disruption.

Jointly solving (1) and (2), the optimal quantity $q_{1}^{f^{*}}$ of Firm 1 and $q_{2}^{f^{*}}$ of Firm 2 to maximize their profits are as follows in (3) and (4), respectively: 
$q_{1}^{f^{*}}=\frac{(1+\lambda)(a-c)}{3+\lambda}$

$q_{2}^{f^{*}}=\frac{a-c}{3+\lambda}$

By substituting (3) into the expression of (1), and (4) into (2), both firms' profits can be obtained as in (5) and (6), respectively:

$\pi_{1}^{f}=(1+\lambda)^{2}\left(\frac{a-c}{3+\lambda}\right)^{2}$

$\pi_{2}^{f}=(1-\lambda)\left(\frac{a-c}{3+\lambda}\right)^{2}$

\section{The Regime of Firm 2's Decision of Purchasing From Firm 1 at the Time of Firm 2's Supply Disruption}

In this subsection, we consider the purchasing regime that Firm 2 purchases products from the rival Firm 1 when it experiences the supply disruption while it does not purchase products when its supply is smooth. In this case, both firms always involve in the Cournot competition. That is, Firm 2 does not outsource the products from Firm 1 if its supply is smooth and delivers the products to the market successfully while it will purchase the products from Firm 1 if supply disruption occurs to Firm 2.

According to the sequence of the events in Figure 1, following Firm 1's announced wholesale price $w$ for Firm 2 to purchase in the case of supply disruption, Firm 2 decides to purchase when supply disruption occurs. Following that, both firms will optimally decide the quantities of the product to deliver to the market, expecting the rival's rational action. Let $q_{1}^{p}$ and $q_{2}^{p}$ represent the quantities of Firm 1 and Firm 2's products to the market, respectively in the regime of purchasing, then Firm 1 's profit $\pi_{1}^{p}$ can be formulated as follows in (7):

$\pi_{1}^{p}=\left(a-q_{1}^{p}-q_{2}^{p}-c\right) q_{1}^{p}+\lambda(w-c) q_{2}^{p}$

and similarly, Firm 2's profit $\pi_{2}^{p}$ is as follows in (8):

$\pi_{2}^{p}=\left(a-q_{1}^{p}-q_{2}^{p}\right) q_{2}^{p}-(1-\lambda) q_{2}^{p} c-\lambda w q_{2}^{p}$

Jointly performing the maximization in (7) and (8), the optimal quantities $q_{1}^{p^{*}}$ and $q_{2}^{p^{*}}$ of Firm 1 and Firm 2 as a function of the wholesale price are as follows in (9) and (10), respectively:

$q_{1}^{p^{*}}=\frac{a-c+\lambda(w-c)}{2}$ 


$$
q_{2}^{p^{*}}=\frac{a-c-2 \lambda(w-c)}{3}
$$

To keep $q_{2}^{p^{*}} \geq 0$, it is necessary that $w-c \leq \frac{a-c}{2 \lambda}$.

By substituting (9) into the expression of (7) and (10) into (8), both firms' profits can be obtained as in (11) and (12), respectively:

$$
\begin{aligned}
& \pi_{1}^{p}=\frac{(a-c)^{2}+5 \lambda(a-c)(w-c)-5 \lambda^{2}(w-c)^{2}}{9} \\
& \pi_{2}^{p}=\left(\frac{(a-c)-2 \lambda(w-c)}{3}\right)^{2}
\end{aligned}
$$

\section{Equilibrium Analysis When Firm 1 is a Central Decision Maker}

In this section, we characterize the equilibrium outcomes when Firm 1 is a central decision maker.

LEMMA 1: In the base setting, Firm 2 will purchase the products from its competitor Firm 1 to hedge against the unexpected supply disruption if and only if:

$$
w \leq c+(a-c)\left(\frac{1}{2 \lambda}-\frac{3 \sqrt{1-\lambda}}{2 \lambda(3+\lambda)}\right)
$$

Lemma 1 shows that Firm 2 is willing to pay the premium to buy the product from its competitor Firm 1 in the case of its supply disruption. The premium it would pay is related to the market size, marginal cost and her supply disruption rate.

Conventional wisdom advises that Firm 1 would never sell its products to its competitor Firm 2 in the common market in order to monopoly the market if Firm 2 experiences disruption and can not supply products. However, as Proposition 1 reveals, this view fails to consider how the sale of products to its competitor Firm 2 to help increase his profit.

PROPOSITION 1: In the base setting, Firm 1 will sell products to its competitor Firm 2 who experiences the supply disruption at the wholesale price:

$$
w=c+(a-c)\left(\frac{1}{2 \lambda}-\frac{3 \sqrt{1-\lambda}}{2 \lambda(3+\lambda)}\right)
$$

By inserting (13) into (11):

$$
\pi_{1}^{p}=\frac{\lambda^{2}+11 \lambda+4}{4(3+\lambda)^{2}}(a-c)^{2}
$$


Proposition 1 indicates that Firm 1 is willing to sell its products to the competitor Firm 2 to help hedge against supply shortage when Firm 2 experiences supply disruption. Since Firm 1's profit expressed in (14) is higher than that in (5), it is motivated by the higher profit achieved in this sale.

By inserting (13) into (9) and (10), respectively, then:

$$
\begin{aligned}
q_{1}^{p^{*}} & =\frac{3(a-c)\left(1-\frac{\sqrt{1-\lambda}}{3+\lambda}\right)}{4} \\
q_{2}^{p^{*}} & =\frac{\sqrt{1-\lambda}}{3+\lambda}(a-c)
\end{aligned}
$$

PROPOSITION 2: See below:

(i) Under purchasing, Firm 2's retail output is lower and profit is the same compared to the profit earned under no purchasing, i.e., $q_{2}^{p^{*}}<q_{2}^{f^{*}}$, and $\pi_{2}^{p}=\pi_{2}^{f}$.

(ii) Under purchasing, Firm 1's retail output is lower and profit is higher compared to the profit earned under no purchasing, i.e., $q_{1}^{p^{*}}<q_{1}^{f^{*}}$, and $\pi_{1}^{p}>\pi_{1}^{f}$.

In more details, both of Firm 1 and Firm 2 deliver a lower quantity to the market in the purchasing regime than in the no-purchasing regime based on the comparison between (3) and (15), (4) and (16), respectively, which softens the competition in the market and lead to a higher market price in the purchasing regime than in the no-purchasing. By purchasing products from the competitor Firm 1, Firm 2 enjoys its presence still in the market when it goes through "zero" supply disruption. In this case, Firm 2's profit comes from two parts: 1) the expected profit from its own delivery of its own products without disruption and 2) the expected profit of the delivery of products purchased from Firm 1 under disruption. Compared to no purchasing when Firm 2 experiences disruption, the expected profit from its own delivery is decreased. However, the expected profit from the products purchased from Firm 1 can offset the effect. Therefore, Firm 2's profit keeps constant under both purchasing and no purchasing ${ }^{1}$.

It is also shown that Firm 1 can earn a higher profit if purchasing exists (Firm 1 selling products to Firm 2 to help hedge against disruption). When Firm 2 purchases the product from Firm 1 in the case of disruption, Firm 1's profit comes from two parts shown in (7): 1) the profit from the retail market presented by the first term in (7); 2) the wholesale profit from Firm 2 presented by the second term in (7). Compared to (7), Firm 1's profit in (1) only comes from the retail market if Firm 2 chooses not to purchase in the event of disruption. By comparing (1) to the first term in (7), it is known that Firm 1 will earn less profit from the retail market in the context of Firm 2's purchasing. However, the wholesale profit from Firm 2 under Firm 2's purchasing will offset this negative effect and further increase the total profit of Firm 1 when Firm 2 chooses to purchase from Firm 1 to hedge against the supply disruption.

\section{Outcomes in the Equilibrium When the Firm 1 is a Decentralized Decision Maker}

In this subsection, we consider the scenario that Firm 1 is a decentralized decision maker and sells the products through an independent retailer $R$. Figure 2 shows the sequences of events when Firm 1 is a decentralized decision maker. As shown in the figure, Firm 1 will announce the wholesale price per unit to the retailer and Firm 2. Following the announcement, Firm 2 will make the decision in purchasing to hedge against her unexpected supply disruption or not. In the context of Firm 2's decision of purchasing from Firm 1, both the retailer and Firm 2 decides the quantities to deliver 


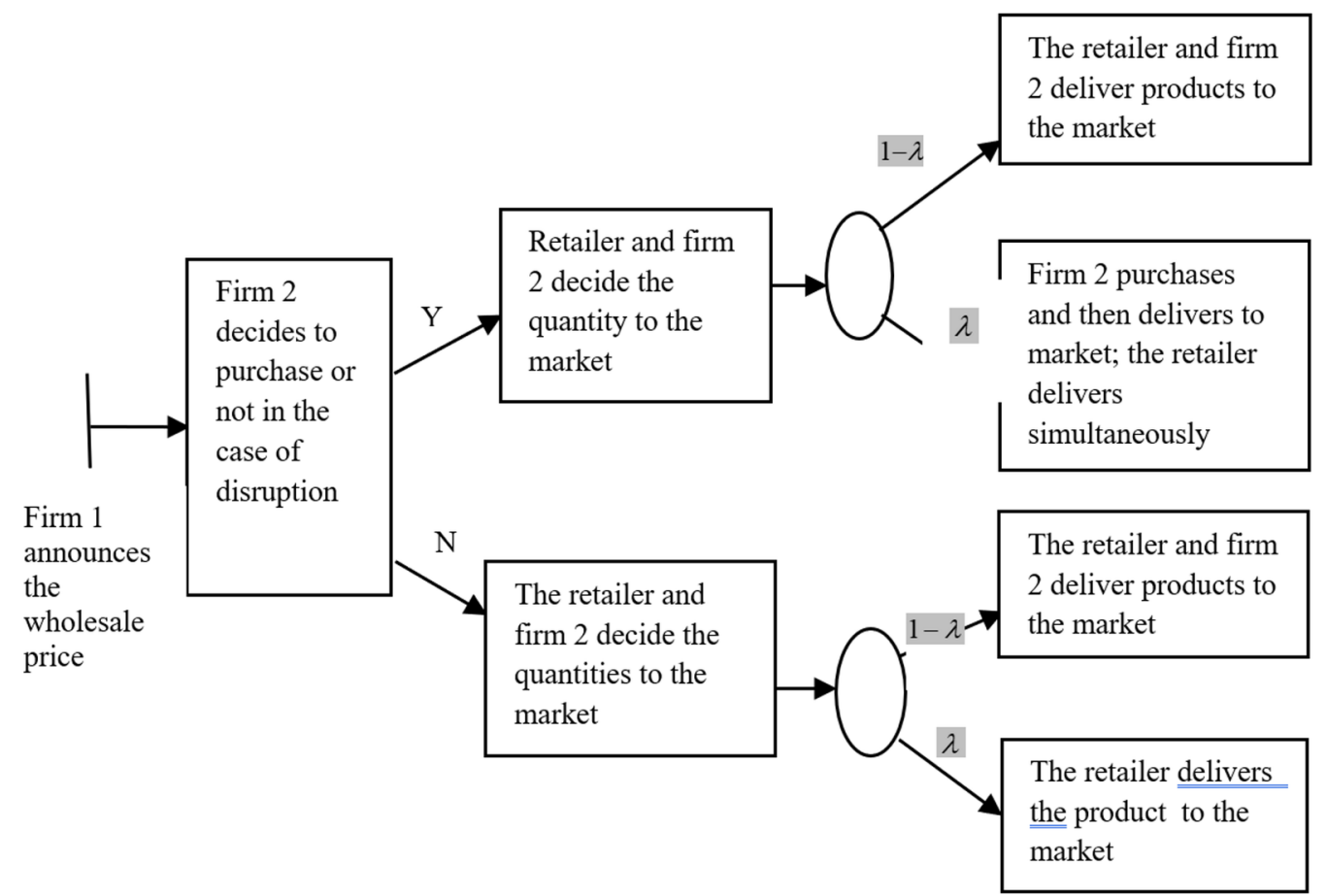

to the market. When Firm 2 experiences the supply disruption, it will purchase the products from Firm 1 and then deliver to the market. However, when Firm 2 supplies the products successfully, it will not purchase the products from Firm 1. Finally, both the retailer and Firm 2 involve in the Cournot competition and the market clears based on the quantities of products delivered by the retailer and Firm 2. In the context of Firm 2's decision of not purchasing from Firm 1, the retailer and Firm 2 will decide the quantities of products to deliver to the market. The final stage is as follows: Firm 2 will be absent from the market when it experiences the supply disruption and then the retailer will monopoly the market. The market clears based on the quantity of products delivered by the retailer. However, both the retailer and Firm 2 involve in the Cournot competition when Firm 2 does not experience the supply disruption and the market clears based on the quantities delivered by both parties.

To analyze whether Firm 2 would purchase the products from the rival Firm 1 or not when she experiences supply disruption, we first obtain the outcomes that follow Firm 2's decision not to purchase when supply disruption occurs. Then we derive the outcomes that follow Firm 2's decision to purchase when supply disruption occurs. We characterize the equilibrium outcomes when Firm 1 is a decentralized decision maker selling his products through a retailer in a decentralized supply chain.

\section{The Regime in Firm 2's Decision of Not Purchasing From} Firm 1 at the Time of Supply Disruption

In this subsection, we consider Firm 2 will not purchase the products from Firm 1 when Firm 2 experiences supply disruption. Based on the sequences of the events in Figure 2, following Firm 1 's announced wholesale price, Firm 2 chooses not to purchase. Then both the retailer and Firm 2 decide the optimal quantities to deliver to the market, respectively. In this context, Firm 1's retailer monopolies the market when Firm 2 experiences supply disruption while both the retailer and Firm 
2 involve in the Cournot competition when Firm 2 smoothly delivers the products to the market. Therefore, mathematically, the retailer's profit can be formulated as follows in (17):

$$
\pi_{R d}^{f}=(1-\lambda)\left(a-q_{R d}^{f}-q_{2 d}^{f}-w_{d}^{f}\right) q_{R d}^{f}+\lambda\left(a-q_{R d}^{f}-w_{d}^{f}\right) q_{R d}^{f}
$$

Similarly, Firm 2's profit can be formulated as follows in (18):

$$
\pi_{2 d}^{f}=(1-\lambda)\left(a-q_{R d}^{f}-q_{2 d}^{f}-c\right) q_{2 d}^{f}
$$

Jointly solving (17) and (18), the optimal quantity of the retailer and of Firm 2 to maximize their own profits are as follows in (19) and (20), respectively:

$$
\begin{aligned}
& {q_{R d}^{f *}}^{*}=\frac{(1+\lambda) a-2 w_{d}^{f}+(1-\lambda) c}{3+\lambda} \\
& {q_{2 d}^{f *}}^{{ }^{*}}=\frac{a+w_{d}^{f}-2 c}{3+\lambda}
\end{aligned}
$$

Firm 1's profit can be formulated as follows in (21):

$$
\pi_{1 d}^{f}=\left(w_{d}^{f}-c\right) q_{R d}^{f *}
$$

By inserting (19) into (21) and based on the first-order condition, the optimal wholesale price announced by Firm $1 w_{d}^{f^{*}}$ is obtained as follows:

$$
w_{d}^{f^{*}}=\frac{(1+\lambda) a+(3-\lambda) c}{4}
$$

Accordingly, the optimal quantity of the retailer and Firm 2 are as follows in (23) and (24), respectively:

$$
\begin{gathered}
q_{R d}^{f *}=\frac{(1+\lambda)(a-c)}{2(3+\lambda)} \\
q_{2 d}^{f *}=\frac{(5+\lambda)(a-c)}{4(3+\lambda)}
\end{gathered}
$$

By inserting (22), (23) and (24) into (17), (18) and (21), the profits of the retailer, Firm 2 and Firm 1 are as follows, respectively: 


$$
\begin{aligned}
& \pi_{R d}^{f}=\frac{(1+\lambda)^{2}(a-c)^{2}}{4(3+\lambda)^{2}} \\
& \pi_{2 d}^{f}=\frac{(1-\lambda)(5+\lambda)^{2}(a-c)^{2}}{16(3+\lambda)^{2}} \\
& \pi_{1 d}^{f}=\frac{(1+\lambda)^{2}(a-c)^{2}}{8(3+\lambda)}
\end{aligned}
$$

\section{The Regime in Firm 2's Decision of Purchasing From}

\section{Firm 1 at the Time of Supply Disruption}

In this subsection, we consider the regime that Firm 2 purchases the product from Firm 1 to hedge against the supply shortage when Firm 2 experiences the supply disruption. In this case, both the retailer and Firm 2 always involves in the Cournot competition regardless of Firm 2's potential supply disruption.

According to the sequences of the events in Figure 2, following Firm 1's announced wholesale price, the retailer and Firm 2 decides the quantities of the products to deliver to the market. Finally, both of the retailer and Firm 2 involve in the Cournot Competition. Let $q_{R d}^{p}$ and $q_{2 d}^{p}$ represent the quantities planned by the retailer and Firm 2 to deliver to the market, respectively, then the retailer's profit can be formulated as follows in (28) and Firm 2's in (29):

$$
\begin{aligned}
& \pi_{R d}^{p}=\left(a-q_{R d}^{p}-q_{2 d}^{p}-w_{d}^{p}\right) q_{R d}^{p} \\
& \pi_{2 d}^{p}=\left(a-q_{R d}^{p}-q_{2 d}^{p}\right) q_{2 d}^{p}-(1-\lambda) c q_{2 d}^{p}-\lambda w_{d}^{p} q_{2 d}^{p}
\end{aligned}
$$

Jointly performing the maximization of (28) and (29), the optimal quantities of the retailer and Firm 2 are as follows in (30) and (31):

$$
\begin{aligned}
& q_{R d}^{p *}=\frac{a-c+(\lambda-2)\left(w_{d}^{p}-c\right)}{3} \\
& q_{2 d}^{p^{*}}=\frac{a-c+(1-2 \lambda)\left(w_{d}^{p}-c\right)}{3}
\end{aligned}
$$

By inserting (31) into (29), then Firm 2's profit is as in (32):

$$
\pi_{2 d}^{p}=\left(\frac{a-c+(1-2 \lambda)\left(w_{d}^{p}-c\right)}{3}\right)^{2}
$$

Similarly, Firm 1's profit can be formulated as follows in (33): 
$\pi_{1 d}^{p}=\left(w_{d}^{p}-c\right) q_{R d}^{p *}+\lambda\left(w_{d}^{p}-c\right) q_{2 d}^{p *}$

By inserting (30) and (31) into (33), then:

$\pi_{1 d}^{p}=\left(w_{d}^{p}-c\right) \frac{(1+\lambda)(a-c)+2\left(\lambda-1-\lambda^{2}\right)\left(w_{d}^{p}-c\right)}{3}$

\section{Equilibrium Analysis When Firm 1 is a Decentralized Decision Maker}

In this section, we characterize the equilibrium outcomes when Firm 1 is a decentralized decision maker. That is, Firm 1 sells its products through a retailer in a decentralized supply chain competing with Firm 2 who experiences potential unexpected supply risk in a common market. Based on the outcomes from the scenarios that 1) Firm 2 does not purchase the products from Firm 1 at the time of Firm 2 experiencing supply disruption in Subsection 3.2.1; 2) Firm 2 purchases the products from Firm 1 at the time of supply disruption in Subsection 3.2.2, what are the equilibrium outcomes when Firm 1 sells its products through a retailer in a decentralized supply chain?

Lemma 2 shows us the condition that Firm 2 purchases the product from Firm 1 to hedge against the supply shortage when it experiences the supply disruption.

LEMMA 2: When:

$w_{d}^{p} \geq c+\left(\frac{3 \sqrt{1-\lambda}(5+\lambda)-4(3+\lambda)}{4(3+\lambda)(1-2 \lambda)}\right)^{+}(a-c)$

Firm 2 will purchase the product from Firm 1 at the time of its supply disruption, where $x^{+}=\max (0, x)$.

Lemma 2 is consistent with Firm 2's profit expressed in (32) which is increasing in the wholesale price charged by Firm 1 . The higher the wholesale price is, the lower the quantity for the retailer to deliver to the market is, which mitigates the competition, so the higher not only the margin profit earned by Firm 2, but also the quantity of the products delivered by Firm 2. Therefore, the profit earned by Firm 2 in the "purchasing" regime will be higher than that in the "no-purchasing" regime when the wholesale price is beyond a threshold.

Now what is the optimal wholesale price for Firm 1 to announce? Proposition 3 shows the answer.

PROPOSITION 3: In the base setting, Firm 1 will help Firm 2 to hedge against the supply disruption by selling products to Firm 2 at the time of Firm 2 experiencing supply disruption:

(i) the optimal wholesale price announced by Firm 1 is:

$$
w_{d}^{p^{*}}=c+\frac{(1+\lambda)}{4\left(1+\lambda^{2}-\lambda\right)}(a-c)
$$

(ii) Firm 1's profit is as follows in (36):

$$
\pi_{1 d}^{p}=\frac{(1+\lambda)^{2}}{24\left(\lambda^{2}+1-\lambda\right)}(a-c)^{2}
$$


Proposition 3 indicates the optimal wholesale price that Firm 1 charges to sell its products to the retailer and its competitor Firm 2 to help hedge against supply shortage when Firm 2 experiences supply disruption. At this wholesale price, Firm 1's profit expressed in (36) in the "purchasing" regime is higher than that in (27) in the "no-purchasing" regime and Firm 2 also achieves a higher profit in the "purchasing" regime. This is a "win-win" game.

Accordingly, by inserting (35) into (30) and (31), respectively, then:

$$
q_{R d}^{p^{*}}=\frac{2+5 \lambda^{2}-5 \lambda}{12\left(1+\lambda^{2}-\lambda\right)}(a-c)
$$

and:

$$
q_{2 d}^{p^{*}}=\frac{5+2 \lambda^{2}-5 \lambda}{12\left(1+\lambda^{2}-\lambda\right)}(a-c)
$$

Proposition 4 makes a comparison of the quantities delivered to the market and wholesale price announced by Firm 1 between the regime of "no purchasing" and regime "purchasing".

PROPOSITION 4: Under Firm 1's decentralized decision making:

(i) $w_{d}^{f^{*}}<w_{d}^{p^{*}}$;

(ii) $q_{R d}^{p *}<q_{R d}^{f *}$;

(iii) When $0.18 \approx \frac{\sqrt{129}-11}{2} \leq \lambda \leq 0.5, q_{2 d}^{p *} \leq q_{2 d}^{f *}$ while when $0<\lambda<\frac{\sqrt{129}-11}{2} \approx 0.18$, $q_{2 d}^{p^{*}}>q_{2 d}^{f^{*}}$.

Proposition 4 shows that i) the wholesale price charged in the "purchasing" is higher than in the "no-purchasing". This is the result of Firm 1 to induce Firm 2 to purchase at the time of disruption to obtain a higher profit, as we explained in i) of Proposition 3; ii) the retailer delivers a lower quantity of the products to the market in the "purchasing" regime. As expressed in (30), the quantity delivered by the retailer is decreasing in the wholesale price. The high wholesale price charged in the "purchasing" regime leads to the low quantity; iii) the quantity of Firm 2 delivered to the market in the "purchasing" regime is higher than that in the "no-purchasing" regime when Firm 2's disruption rate is lower while it is lower when the disruption rate is higher. This is because both quantities as shown in (24) and (38) decrease in the disruption rate, respectively. However, the quantity in (38) decreases more than in (24). Therefore, the quantity of firm 2 is higher in the "purchasing" at the lower side of the disruption rate regime while it is lower at the higher side of disruption rate.

\section{Supply Chain Structure}

In the previous sections, the outcomes show that Firm 1 will always induce Firm 2 to purchase the products at the time of supply disruption to hedge against its supply shortage whether Firm 1 chooses central decision making or decentralized decision making. In this subsection, we would like to answer the question: 1) how does Firm 1 behave in its retail market? 2) Does Firm 1 choose central decision making or decentralized decision making when its rival has a potential supply disruption and purchases products from it at the time of experiencing supply disruption? The results are summarized in Lemma 3 and Proposition 5. 
LEMMA 3: See below:

(i) $q_{1}^{p^{*}}>q_{R d}^{p *}$

(ii) $a-q_{1}^{p^{*}}-q_{2}^{p^{*}}<w_{d}^{p^{*}}$

Lemma 3 shows that i) Firm 1's quantity in the retail market is higher in the central decision making than in the decentralized decision making. This result is due to the double marginalization in the decentralized decision making; ii) The margin profit for Firm 1 to earn in the retail market is lower in the central decision making due to the aggressive encroachment in the retail market.

PROPOSITION 5: Firm 1 will choose centralized decision making and sells its products through its centralized supply chain.

Proposition 5 shows that Firm 1's centralized supply chain is preferred. This result provides a new insight for the supplier to provide the product to the firms in the common market, compared to the result from Arya, Mittendorf and Yoon (2008) who showed that the VIP profit is always higher under decentralization than under centralization when the rival is $100 \%$ depends on the purchase from the manufacturing company. Our results show that if the rival only purchases the product under her disruption, the manufacturing company's centralized supply chain is preferred.

\section{CONCLUSION}

Outsourcing the products to the rival party in the common market has garnered much attention in operations management. The conventional view posits that monopolization is preferred when the rival experiences disruption and shortages in the market. This paper demonstrates that it may not be the case when both parties sell the products in the common market. In such a case, one party would induce the rival party in the event of disruption to purchase the products from it which actually can earn a higher profit compared to monopolization regardless of the disruption rate. Accordingly, the rival party does not lose its presence on the market when it experiences the disruption and finally earns a higher profit too.

Central decision making eliminates double marginalization, which increases the quantity delivered to the market. However, the firm is able to commit to aggressive encroachment in the market, which in turn may lead to a lower margin profit. This paper's results demonstrate that a judicious structure best balances profitability. Given the prevalence of circumstances wherein the rival experiences disruption, the results shed some light on efficacy of chain forms. That is, the central decision making is preferred.

Given the results demonstrated in this paper, we hope that this study will serve as a stepping stone for future research to explore the ways to mitigate the supply disruption risk including in the situation that firms may have different risk attitudes. 


\section{REFERENCES}

Ang, E., Iancu, D. A., \& Swinney, R. (2017). Disruption risk and optimal sourcing in multitier supply networks. Management Science, 63(8), 2397-2419.

Arya, A., Mittendorf, B., \& Sappington, D. E. M. (2008). The make-or-buy decision in the presence of a rival: Strategic outsourcing to a common supplier. Management Science, 54(10), 1747-1758.

Arya, A., Mittendorf, B., \& Yoon, D. H. (2008). Friction in related-party trade when a rival is also a customer. Management Science, 54(11), 1850-1860.

Bennett, J., \& Hromadko, J. (2012, April 18). Nylon-12 haunts car makers; explosion at big supplier of resin for automotive parts has industry fearing potential shortages. Wall Street Journal. Retrieved from http://online. wsj.com/article/SB10001424052702304432704577349883297625686.html

Chen, J., \& Guo, Z. (2014). Strategic sourcing in the presence of uncertain supply and retail competition. Production and Operations Management, 23(10), 1748-1760.

Clark, D. (2012, April 18). Earnings: Intel expects PCs to help chip gains. Wall Street Journal. Retrieved from http://online.wsj.com/article/SB10001424052702304299304577350182106508566.html

Demirel, S., Kapuscinski, R., \& Yu, M. (2018). Strategic behavior of suppliers in the face of production disruptions. Management Science, 64(2), 533-551.

Federgruen, A., \& Yang, N. (2008). Selecting a portfolio of suppliers under demand and supply risks. Operations Research, 56(4), 916-936.

Henig, M., \& Gerchak, Y. (1990). The structure of period review policies in the presence of variable yield. Operations Research, 38(4), 634-643.

Hu, B., \& Kostamis, D. (2014). Managing supply disruptions when sourcing from reliable and unreliable suppliers. Production and Operations Management, 24(5), 808-820.

Hu, X., Gurnani, H., \& Wang, L. (2013). Managing risk of supply disruptions: Incentives for capacity restoration. Production and Operations Management, 22(1), 137-150.

Kouvelis, P., \& Li, J. (2013). Offshore outsourcing, yield uncertainty, and contingency responses. Production and Operations Management, 22(1), 164-177.

Nguyen, C. (2013). Why Apple can't escape Samsung: Globalization. Retrieved from http://www.gottabemobile. com/2013/05/22/why-apple-cant-escape-samsung-globalization/

Qin, Z. (2013). The effect of "make" or "buy" on the timing of capacity investment by manufacturers in new markets. International Journal of Applied Management Science, 5(4), 377-396.

Spiegel, Y. (1993). Horizontal subcontracting. The Rand Journal of Economics, 24(4), 570-590.

Tabuchi, H. (2011). Toyota says no full production until Year's end. The New York Times. Retrieved from http:// www.nytimes.com/2011/04/23/business/global/23toyota.html?+

Tomlin, B. (2006). On the value of mitigation and contingency strategies for managing supply chain disruption risks. Management Science, 52(5), 639-657.

Tomlin, B. (2009). Impact of supply learning when suppliers are unreliable. Manufacturing \& Service Operations Management: $M$ \& SOM, 11(2), 192-209.

Tomlin, B., \& Wang, Y. (2011). Operational strategies for managing supply chain disruption risk. in the Handbook of integrated risk management. Hoboken, NJ: John Wiley \& Sons, Inc.

Wadecki, A. A., Babich, V., \& Wu, O. (2010). Manufacturer's competition and subsidies to suppliers (Working paper). Retrieved from http://papers.ssrn.com/sol3/papers.cfm?abstractnid=1616949

Yang, Z., \& Babich, B. (2015). Does a procurement service provider generate value for the buyer through information about supply risks? Management Science, 61(5), 979-998. 


\section{ENDNOTES}

1 Since firm 2 still maintains her presence on the market when she experiences the supply disruption, she would choose to purchase products from firm 1 to hedge against supply shortage even the profits in the regime of no purchasing and purchasing are the same.

Zhaoqiong Qin is an assistant professor in University of Central Oklahoma. Her research interests focus on behavior interactions among parties in supply chain management, operations research, optimization and decision sciences. Her seminal work is published in Operations Research, International Journal of Logistics: Research and Application and International Journal of Applied Management Science. 


\section{APPENDIX}

PROOF OF LEMMA 1: If Firm 2 can earn a higher profit by buying the products from Firm 1 to hedge against the unexpected supply disruption compared to the earned profit by not buying from Firm 1, then Firm 2 will choose to buy. That is $(12) \geq(6)$. So only when $w \leq c+(a-c)\left(\frac{1}{2 \lambda}-\frac{3 \sqrt{1-\lambda}}{2 \lambda(3+\lambda)}\right)$, Firm 2 will buy products from Firm 1 to hedge against the unexpected supply disruption.

PROOF OF PROPOSITION 1: To make Firm 1's profit in Firm 2's purchasing regime is higher than the profit without purchasing, the following condition should be satisfied:

$$
c+(a-c)\left(\frac{1}{2 \lambda}-\frac{\sqrt{225-90 \lambda-135 \lambda^{2}}}{10 \lambda(3+\lambda)}\right) \leq w \leq c+(a-c)\left(\frac{1}{2 \lambda}+\frac{\sqrt{225-90 \lambda-135 \lambda^{2}}}{10 \lambda(3+\lambda)}\right)
$$

To induce Firm 2 to purchase the product from its rival Firm 1 in the case of supply disruption:

$$
w \leq c+(a-c)\left(\frac{1}{2 \lambda}-\frac{3 \sqrt{1-\lambda}}{2 \lambda(3+\lambda)}\right)
$$

Since:

$$
\begin{aligned}
& \frac{\sqrt{225-90 \lambda-135 \lambda^{2}}}{5}>3 \sqrt{1-\lambda} \\
& c+(a-c)\left(\frac{1}{2 \lambda} \frac{\sqrt{225-90 \lambda-135 \lambda^{2}}}{10 \lambda(3+\lambda)}\right)<c+(a-c)\left(\frac{1}{2 \lambda}-\frac{3 \sqrt{1-\lambda}}{2 \lambda(3+\lambda)}\right)<c+\frac{a-c}{2 \lambda}
\end{aligned}
$$

From (11), it is also known that Firm 1 will achieve the maximum profit at $w=c+\frac{a-c}{2 \lambda}$. Therefore Firm 1 will announce the wholesale price at:

$$
w^{*}=c+(a-c)\left(\frac{1}{2 \lambda}-\frac{3 \sqrt{1-\lambda}}{2 \lambda(3+\lambda)}\right)
$$

PROOF OF LEMMA 2: In the decentralized decision case, if Firm 2 can earn a higher profit by buying the products from Firm 1 to hedge against the unexpected supply disruption compared to the earned profit by not buying from Firm 1, then Firm 2 will choose to buy. That is $(30) \geq(24)$, i.e. when:

$$
w_{d}^{p} \geq c+(a-c)\left(\frac{3 \sqrt{1-\lambda}(5+\lambda)-4(3+\lambda)}{4(3+\lambda)(1-2 \lambda)}\right)
$$


Firm 2 will purchase the product from Firm 1 in the event of supply disruption.

PROOF OF PROPOSITION 3: See below:

(i) To make (32) is higher than (25), that is, Firm 1 will make a higher profit in the purchasing, then:

$$
(a-c)(1+\lambda) \frac{1-\sqrt{1-\frac{3\left(1+\lambda^{2}-\lambda\right)}{3+\lambda}}}{4\left(1+\lambda^{2}-\lambda\right)}<w_{d}^{p}-c<(a-c)(1+\lambda) \frac{1+\sqrt{1-\frac{3\left(1+\lambda^{2}-\lambda\right)}{3+\lambda}}}{4\left(1+\lambda^{2}-\lambda\right)}
$$

When $\lambda \leq \frac{1}{2}, 285-734 \lambda-309 \lambda^{3}+742 \lambda^{2}>0$. Therefore:

$$
285 \lambda-734 \lambda^{2}-309 \lambda^{4}+742 \lambda^{3}+4 \lambda^{5}+63 \lambda^{6}+9 \lambda^{7}>0
$$

So it is clear that:

$$
\frac{(1+\lambda)(a-c)}{4\left(\lambda^{2}+1-\lambda\right)}>\frac{3 \sqrt{1-\lambda}(5+\lambda)-4(3+\lambda)}{4(3+\lambda)(1-2 \lambda)}(a-c)
$$

Based on the first-order condition in (32), when $w_{d}^{p}-c=\frac{(1+\lambda)(a-c)}{4\left(1+\lambda^{2}-\lambda\right)}$, (32) is maximized. Based on Lemma 2, the maximizer of (32) also can guarantees Firm 2 purchases products from Firm 1 at the time of supply disruption. Therefore, Firm 1 announces the wholesale price $w_{d}^{p^{*}}=c+\frac{(1+\lambda)(a-c)}{4\left(\lambda^{2}+1-\lambda\right)}$.

Firm 1 will announce $w_{d}^{p^{*}}=c+\frac{21}{44 \lambda}(a-c)$ to maximize its own profit.

(ii) By inserting $w_{d}^{p^{*}}$ into (32):

$$
\pi_{1 d}^{p}=\frac{(1+\lambda)^{2}}{24\left(\lambda^{2}+1-\lambda\right)}(a-c)^{2}
$$

PROOF OF PROPOSITION 4: See below:

(i) When $0.18 \leq \lambda \leq 0.5,2-\lambda^{2}-11 \lambda \leq 0$, (36) $<(22)$, i.e., $q_{2 d}^{p *} \leq q_{2 d}^{f}{ }^{*}$, while when $\lambda<0.18,2-\lambda^{2}-11 \lambda>0,(36)>(22)$, i.e., $q_{2 d}^{p *}>q_{2 d}^{f *}$

(ii) Since $10 \lambda^{2}-13 \lambda-\lambda^{3}<0,(35)<(21)$, i.e., $q_{R d}^{p}{ }^{*}<q_{R d}^{f}$;

(iii) Since $\lambda\left(\lambda^{2}-1\right)(a-c)<0$, the $(20)<(33)$, i.e., $w_{d}^{f^{*}}<w_{d}^{p^{*}}$. 
PROOF OF PROPOSITION 5: When $7 \lambda^{2}+152 \lambda-47 \leq 0$, Firm 1's profit in (38) is higher than or equal to that in (14), i.e., $0<\lambda \leq \frac{\sqrt{6105}-76}{7} \approx 0.3$, Firm 1's profit in the decentralized supply chain will be higher than or equal to the profit in the centralized supply chain. Therefore Firm 1 will choose a decentralized supply chain and sell its products through the retailer. Otherwise it will choose the centralized supply chain to sell its products. 